\section{Role of Sowing Time in Maize Production (Review)}

\author{
Ferenc Rácz - Ottó Illés - István Pók - \\ Csaba Szőke - Zsuzsanna Zsubori \\ Agricultural Research Institute of the Hungarian Academy of \\ Sciences, Martonvásár
}

\section{SUMMARY}

Many authors, both in Hungary and abroad, have reported on experiments carried out to determine the role of sowing time in maize, but the results are often contradictory. This is hardly surprising, since the maize plant exhibits enormous genetic variability and the hybrids created through selection and inbreeding may have very specific requirements as to sowing date. The year effect, too, often complicates the efforts of scientists to provide clear guidance to farmers on the optimal sowing date for each hybrid.

Even in more dated Hungarian literature, numerous data can be found encouraging farmers to sow maize earlier than usual. The works of Pethe (1817) and Balás (1889) all suggest that if good quality seed is used, a larger, more reliable yield will be obtained, with earlier ripening, if sowing is carried out earlier than usual.

I'só (1966) pointed out that correct views on the sowing date of maize were already general in Hungary in the $19^{\text {th }}$ century.

The results of a three-year series of experiments carried out by Pásztor (1958) indicated that a correct choice of sowing date had a favourable effect on both the vegetation period and on the yield. However, it is also important to taken variety characteristics into account, since the varieties included in the experiments did not all have the same sowing date optimum. For this reason, and due to the fact that the same hybrid may have different optimal sowing dates in different years, there is no consensus among experts in this respect, as noted by I'só (1962).

According to Kovács (1957) most of the contradictions concerning the correct sowing date stem from the fact that seed quality is ignored.

All in all, however, early sowing can be said to be more favourable, as shown by the results of sowing time experiments (I'só, 1962), although Pásztor (1962) considered sowing in the first ten days of May to be optimal.

The results of sowing time experiments carried out by Győrffy et al. (1965), I'só (1966) and Pásztor (1966) indicated that hybrids with short vegetation periods are less sensitive to late sowing. However, the sowing date is influenced not only by the hybrid, but also by the soil. Soils with better heat management warm up more quickly, so sowing can be carried out between April $10^{\text {th }}$ and $25^{\text {th }}$, while on soils with poor heat management the optimal sowing date is between April $25^{\text {th }}$ and May $5^{\text {th }}$. This question, however, is also considerably influenced by seed quality (Menyhért, 1985).
Behaeghe et al. (1981) also regarded sowing prior to May $5^{\text {th }}$ to be optimal, since higher grain moisture was generally recorded at harvest in the case of later sowing. Johnson and Mulvaney (1980) considered sowing on May $6^{\text {th }}$ to be the most favourable, while sowing two weeks later led to a 5\% yield loss.

Similaru (1986) found a much earlier sowing date to be optimal. On soil with satisfactory nutrient supplies, the optimal sowing date was found to be between April $15^{\text {th }}$ and April $20^{\text {th }}$, with a plant density of 50-60 thousand per hectare. Tomoroga et al. (1985), on the other hand, recorded yield losses even when sowing was carried out in late April.

According to Sárvári and Futó $(2001 \mathrm{a}, \mathrm{b})$, for some hybrids early sowing leads to an outstanding increase in yield and to lower grain moisture content at harvest, thus improving production efficiency. They thus recommend a variety-specific technology which adapts the sowing date to the hybrids in coordination with other production factors.

Bauer and Carter (1986) not only found a correlation between the sowing date and the grain yield, but noted that later sowing led to more brittle grains, causing storage problems. In addition, there was a $4-6 \%$ reduction in the grain yield per hectare in late-sown plots. Grain brittleness was also increased in this experiment by high stand density, poor nitrogen supplies and irrigation.

Imholte and Carter (1987) and Russelle et al. (1988) also found that late sowing reduced the grain yield and increased the grain moisture content at harvest.

It can thus be seen that, as time passed and an increasing number of results were published in connection with the sowing date, opinions on the best sowing date began to concur and the majority of scientists and growers now agree that early or midearly sowing has a positive effect.

The relationship between sowing date and yield is, however, indirect, since this factor exerts its effect by promoting a healthy, well-developed plant stand with satisfactory vegetative mass.

According to Popov (1979) the incidence of mosaic virus infection was lower when sowing was carried out in April, as a consequence of which higher yields were harvested in early-sown fields.

Bergmann and Turpin (1984), however, drew attention to the negative aspects of early sowing. When investigating the relationship between sowing date and plant protection they found that sowing in April significantly increased the presence of Diabrotica spp. larvae in the stand. This was explained by the fact that L1 larvae found feed plants if the maize was sown early, but not if it was sown 
late. On areas severely infested with black cutworm it may thus be wise to plant the maize relatively late.

In experiments carried out by Berzsenyi et al. (1998a, b, c, d; 1999) in 1995 and 1996 using five hybrids with different vegetation periods, early sowing was found to promote reproductive growth and late sowing initial vegetative growth. The leaves appeared more rapidly in late-sown crops, but the final leaf number was not influenced by the sowing date.

It can be seen from the above that temperature may be a limiting factor for both the vegetative and generative development of maize.

Bocz (1996) agreed that this was a fundamental factor in maize production. The great temperature fluctuations experienced in spring and autumn do not favour maize development. If the weather warms up too slowly in spring, emergence will be delayed, retarding the development of the young plants.

The assimilation heat threshold for maize was determined many years ago to be $10^{\circ} \mathrm{C}$, and this value is still used today. However, maize genotypes which have become adapted to the temperate zone now have a lower assimilation heat threshold. Recent calculations in Hungary indicate that the heat threshold should be modified to $6-8^{\circ} \mathrm{C}$.

When examining the heat threshold for emergence Herczegh and Marton (1986) found that some hybrids started developing at $4^{\circ} \mathrm{C}$, while others required at least $8^{\circ} \mathrm{C}$. Bunting (1976) also reported that the temperature threshold for maize was below $10^{\circ} \mathrm{C}$, and recommended a modification of the accepted value. It is extremely important to establish this threshold for the given maize hybrid, since this will determine when sowing can be carried out. If the seed is sown before this temperature is reached the plant may suffer damage and development will be retarded. This damage is not the same as frost damage, since the frost tolerance of hybrids with good cold tolerance does not generally differ from that of maize hybrids with a higher temperature threshold (Khehra et al., 1987).

Marton et al. (1997) also found that different maize genotypes had different cold tolerance levels. When six genetically different inbred lines were tested at $10^{\circ} \mathrm{C}$, a significant difference was found in their seedling cold tolerance, two variants of which could be distinguished. The first had rapid initial development even during a short period of cold, while the other exhibited slow growth intensity but was able to survive a very long period of cold. In Hungary, the first type is more favourable, since the cold periods experienced after sowing do not last for weeks (Gupta and Kovács, 1976).

The question arises whether it is possible to select for genotypes with better cold tolerance on the basis of phenotypic or genotypic traits. Mock and Skrdla (1978) considered this possible. They studied the germination percentage, germination vigour and dry weight of 42-day-old plants for 144 hybrids tested in a climatic chamber at $10^{\circ} \mathrm{C}$ and found large genotypic variance, suggesting that selection would be effective. For the 25 hybrids with the best cold tolerance, the germination percentage was $96.6 \%$, the germination vigour 15.6 days and the dry matter content of 42-day-old plants $10 \mathrm{~g} / \mathrm{plant}$. No correlation was found between cold tolerance and flowering date.

When investigating maize lines and hybrids, Hodges et al. (1997) found that in the course of development the cold tolerance of the genotypes changed. Studies on cold tolerance at emergence and during initial development indicated that these traits were determined by different factors and that the cold tolerance of the hybrids could not be deduced from that of the parental lines. Dhillon et al. (1993), however, considered that selection for cold tolerance could be made when sowing was carried out at the normal date on the basis of leaf yellowing.

Semuguruka et al. (1981) also reported that, although the hybrids had different levels of cold tolerance, hybrids less tolerant of cold were able to regenerate at higher temperature.

Maize plants are thus damaged by cold, and some of the damage only becomes visible when the weather warms up. According to Szalai et al. (1996), damage is only likely to occur during the early stages of development. Some of the changes occurring due to cold are in positive correlation with the low temperature-induced synthesis of certain compounds (Dőry et al., 1990; Lasztity et al., 1994; Rácz et al., 1996; Páldi et al., 1996; Janda et al., 1996). A number of nitrogen-containing compounds, such as putrescine, agmatine, proline and glycine-betain are regarded as stress markers (Páldi et al., 1998).

Five inbred lines with different levels of cold tolerance were investigated by Páldi et al. (1996) to determine whether these compounds played any role in maize cold tolerance. It was found that the quantities of putrescine, agmatine and proline changed at low temperature and that these changes were correlated with maize cold tolerance.

In cool, wet springs the maize shows protracted emergence and slow development. It is thus important to determine which genotypes are capable of tolerating unfavourable conditions in early spring. Tatum (1942) was the first to elaborate a laboratory method, which later served as the basis for the cold test (Bochicchio, 1985), the aim of which is to test seed lots under the less favourable conditions existing in the field, in order to obtain a realistic picture of seed quality. The method was later made more uniform in order to make comparisons easier (Isely, 1950; Clark, 1954). Hoppe (1951) made an important contribution to the perfection of the method, while Kovács $(1958 ; 1961)$ adapted it to Hungarian conditions.

As reported by Delouche (1976) and Marton (1997), the seed vigour evaluations provided by the cold test are greatly influenced by external factors, such as seed dressing. Many authors thus suggest that cold tolerance should also be tested in sterilised soil or in artificial media (Tatum and Zuber, 1943; Kovács, 1961; Maryam and Jones, 1983; Christeller, 1984; Bocsi, 1988). 
According to Menyhért (1985), the sowing date of maize hybrids is influenced not only by the cold test values, but also by the genetic traits of the hybrid, the length of the vegetation period, the soil temperature and the seed quality. In the case of early sowing the maize soon shades the soil, thus reducing soil evaporation. If the plant then receives sufficient light and heat during flowering and fertilisation, more grains will develop. Early-sown maize also has more time for the development of the root system, which thus penetrates to a greater depth, possibly allowing the plant to absorb water from deeper layers even during flowering. In addition, early-sown maize produces more compact plants with a more favourable harvest index. The ears grow at a lower height, giving relatively greater lodging resistance. The yield is also better than after late sowing.

This was confirmed by the results of Györffy et al. (1965), who found that a month's delay in sowing led to yield losses of $20-25 \%$. In experiments carried out over a ten-year period, Rossmann and Cook (1966) observed that the grain yield was reduced by $9 \%$ when sowing was delayed for 10 days, by $16 \%$ after 20 days and by $27 \%$ when sowing was 30 days late.

According to Menyhért (1985) the optimal sowing date in Hungary is between April $10^{\text {th }}$ and May $5^{\text {th }}$. This author found that, in addition to the advantages outlined above, early sowing also led to better fertiliser utilisation by the crop, especially in the case of nitrogen.

It can thus be seen that, despite the differences of opinion often expressed by scientists and growers in past decades, a consensus is gradually developing, and it is now the general opinion in Hungary that mid-early or early sowing is optimal for maize.

In Martonvásár Berzsenyi et al. (1998b) consider the period between April $20^{\text {th }}$ and $25^{\text {th }}$ to be the ideal sowing date.

\section{REFERENCES}

Balás, Á. (1889): Általános és különleges mezőgazdasági növénytermelés. 2. kötet. 92.

Bauer, P. J.-Carter, P. R.. (1986): Effect of seeding date, plant density, moisture availability, and soil nitrogen fertility on maize kernel breakage susceptibility.: Crop., Sci., 26. 12201226.

Behaeghe, T.-Vanbockstaele, E.-De Baets. (1981): Le mais comme culture de fourrages grossiers 4. Mais: l' importance du peuplement, de la date de semmis, de récolte et d' une éventuelle fumure en localisé. Synthése de résultats récents. REV. Agric. Bruxeles, 34. 577-593.

Bergmann, M. K.-Turpin, F. T. (1984): Effect of sowing date on the dynamics of populations of Diabrotica spp. in maize. Envir. Ent., College Park, 13. 888-901.

Berzsenyi, Z.-Ragab, A. Y.-Lap, D. Q. (1998a): A vetésidő hatása a kukoricahibridek vegetatív növekedésének dinamikájára 1995-ben és 1996-ban. Növénytermelés. 160-180.

Berzsenyi, Z.-Ragab, A. Y.-Lap, D. Q. (1998b): A vetésidő hatásának vizsgálata a kukorica (Zea mays L.) hibridek növekedésére aszimptotikus függvényekkel. Növénytermelés. 525-545.

Berzsenyi, Z.-Ragab, A. Y.-Lap, D. Q. (1998c): A vetésidő hatásának vizsgálata a kukorica (Zea mays L.) hibridek növekedési jellemzöire (a klasszikus módszer és a HP-modell összehasonlítása). Növénytermelés. 655-676.

Berzsenyi, Z.-Ragab, A. Y.-Lap, D. Q. (1998d): A vetésidő hatása a kukorica hibridek reproduktív növekedésének dinamikájára és a szemtermés komponensekre. Növénytermelés. 423-437.

Berzsenyi, Z.-Ragab, A. Y.-Lap, D. Q. (1999): A vetésidő hatásának vizsgálata kukorica szemtermésének növekedési dinamikájára, Richards függvénnyel. Növénytermelés. 167187.

Bochicchio, A. (1985): Zea mays $L$. and chilling conditions at sowing time: Review. Maydica, 241-256.

Bocz, E (1996): Szántóföldi növénytermesztés. Mezőgazda Kiadó, Budapest

Bocsi, J. (1988): Kukorica (Zea mays L.) csíranövények hidegtürésének tanulmányozása in vitro steril körülmények között. Növénytermelés. 421-429.
Bunting, E. S. (1976): Accumulated temperature and maize development in England. J. Agric. Sci. Camb. 557-583.

Christeller, J. I. (1984): Seedling growth of Zea mays at $13^{\circ} \mathrm{C}$. Comparison of Corn Belt dent hybrid and a hybrid selected for rapid plumule emergence at cool temperatures. J. Exp. Bot, 955-964.

Clark, B. E. (1954): Factors effecting the germination of sweet corn in low temperature laboratory tests. Bulletin 769. New York State Agr. Exp. Sta. Geneva

Delouche, J. C. (1976): Standardization of vigor tests. Journal of Seed Tech., 1. 75-85.

Dhillon, B. S.-Dey, S. K.-Bansal, U. K.-Kapoor, W. R.-Verma, M. M. (1993): Inbred-hybrid correlations for cold tolerance in maize. Heterosis breeding in crop plants - theory and applycation: short communications: symposium Ludhiana, 2324 February 1993

Dőry, I.-Böddi, B.-Kissimon, J.-Páldi, E. (1990): Cold stress responses if inbreed maize lines with various degrees of cold tolerance. Acta Agron. Hung. 39. 309-318.

Gupta, G.-Kovács, I. (1976): Cold wave tolerance of the opaque-2 maiz seedlings and their normal analogues, and relationship of the cold wave tolerance with cold test data. Z. für Acker-und Pflanenbau, 143. 196-203.

Győrffy, B.-I’só, I.-Bölöni, I. (1965): Kukoricatermesztés. Mezőgazdasági Kiadó, Budapest

Herczegh, M.-Marton, L. Cs. (1986): Cold stress of maize in a temperature gradient chamber. In: Breeding of silage maize (Eds.: Dolstra, D.-Miedema, P.) Wageningen, 56-60.

Hodges, D. M.-Andrews, C. J.-Johnson, D. A.-Hamilton, R. I. (1997): Sensitivity of maize hybrids to chilling and their combining abilities at two developmental stages. Crop Science. 850-856.

Hoppe, P. E. (1951): A new technique for incubating seed corn in cold soil for disease test. Phytopathology, 747-751.

I'só, I. (1962): Vetésidő és fajtakísérletek kukoricával. In: I’só (ed.), Kukoricatermesztési kísérletek 1958-1960. Akadémiai Kiadó, Budapest. 138-142.

I’só, I. (1966): Vetésidő fajtakísérletek kukoricával. In: I'só (ed.), Kukoricatermesztési kísérletek 1961-1964. Akadémiai Kiadó, Budapest. 224-232. 
Imholte, A. A.-Carter, P. R. (1987): Planting date and tillage effects on corn following corn. Agron. J. 746-751.

Isley D. (1950): The cold test of corn. Proc. Int. Seed Test. Assoc., 16. 199-311.

Janda, T.-Szalai, G.-Páldi, E. (1996): Clorophyll fluorescense and anthocyanin content in chilled maize plants and after returned to a non-chilling temperature under various light conditions. Biol. Plant. 625-627.

Johnson, R. R.-Mulvaney, D. L. (1980): Development of a model for use maize replant decisions. Agron J. Madison, 459-464.

Khehra, A. S.-Sharma, R. K.-Dhillon, B. S. (1987): Laboratory studies on freezing injury in maize. Ind. J. Agric. Sci. 57. 176178.

Kovács, I. (1957): A kukorica hidegtủrő képességének vizsgálata különös tekintettel az optimális vetésidő megállapítására. In: I'só (ed.), Kukoricatermesztési kísérletek 1953-1957. Akadémiai Kiadó, Budapest. 189-203.

Kovács, I. (1958): A kukorica hidegtürő képességének fokozása különös tekintettel a koraiságra, a termés nagyságára és biztonságára. Kandidátusi disszertáció. Martonvásár

Kovács, I. (1961): A „hidegpróba” alkalmazása a kukorica hidegtürő képességének fokozására irányuló nemesítésben. Növénytermelés. 10. 27-42.

Lásztity， D.-Rácz， I.-Páldi， E. (1994): Activity of protein synthesising system in vernalised wheat seedlings a low temperature. In: K. Dörffling-B. Brettschneider-H. Tantau-K. Pithan (ed): Crop Adaptation to Cool Climates, CED, Brussels-Luxembourg, 349-354.

Marton, L. C.-Szundy, T.-Nagy, E. (1997): A kukorica (Zea mays L.) fiatalkori hidegtúrésének értékelése hömérsékleti gradiens kamrában. Növénytermelés. 549-557.

Maryam, B.-Jones, D. A. (1983): The genetics of maize (Zea mays L.) growing at low temperature. I. Germination of inbred lines and their F1-s. Euphytica, 535-542.

Menyhért, Z. (1985): A kukoricatermesztés kézikönyve. Mezőgazdasági Kiadó, Budapest

Mock, J. J.-Skrdla, W. H. (1978): Evaulation of maize plant introductions for cold tolerance. Euphytica, Wageningen. 27. 27-32.

Páldi, E.-Rácz, I.-Lásztity, D. (1996): Effect of low temperature on the $r$ RNA processing in wheat (Triticum aestivum). J. Plant Physiol. 368-373.

Páldi, E.-Szalai, G.-Janda, T.-Marton, L. C. (1998): Az alacsony hőmérséklet hatása egyes $\mathrm{N}$-tartalmú vegyületek szintézisére különböző hidegtürésủ beltenyésztett kukorica vonalakban. Növénytermelés. 483-490.

Pásztor, K. (1958): Vetésidő fajtakísérletek kukoricával. In: I'só (ed.), Kukoricatermesztési kísérletek 1953-1957. Akadémiai Kiadó, Budapest. 169-188.
Pásztor, K. (1962): Újabb kísérleti adatok a kukorica vetésidejéhez. In: I'só (ed.), Kukoricatermesztési kísérletek 1958-1960. Akadémiai Kiadó, Budapest. 143-152.

Pásztor, K. (1966): A vetésidő és a vetésmélység hatása a kukorica termésére. In: I'só (ed.), Kukoricatermesztési kísérletek 19611964. Akadémiai Kiadó, Budapest. 240-251.

Pethe, F. (1817): A kukoricatermesztésnek igen hasznos módja. Nemzeti Gazda. 4. 15. 229-230.

Popov, A. (1979): Mosaic virus infection in maize as a function of sowing date. Raszten. Nauki, 16. 82-87.

Rácz, I.-Kovács, M.-Lásztity, D.-Veisz, O.-Szalai, G.-Páldi, E. (1996): Effect of short term and long-term low temperature stress on polyamine biosynthesis in wheat genotypes with varying degrees of fros tolerance.) J. Plant Physiol. 368-373.

Rossmann, E. C.-Cook, R. L. (1966): Soil preparation and date, rate and pattern of planting. In andvances, in corn production: Principles and practices, 53-101.

Russelle, M. P.-Olson, R. A.-Hauck, R. D. (1987): Planting date and nitrogen management interactions in irrigated maize. Field Crops Res., Amsterdam, 349-362.

Sárvári, M.-Futó, Z. (2001a): A vetésidő hatása a különböző genetikai adottságú kukoricahibridek termésére. Növénytermelés. 43-60.

Sárvári, M.-Futó, Z. (2001b): Összefüggés a kukoricahibridek vetésideje, produkciója és a betakarításkori nedvességtartalma között csernozjom talajon. Agrártudományi közlemények. 1. $32-41$

Semuguruka, G. H.-Compton, W. A.-Sullivan, C. Y.-Thomas, M. A. (1981): Some measures of temperature response in corn. (Zea mays L.)Maydica, 209-218.

Similaru, E. (1986): Epoca si desimea de semanat - verigi de baza ale technologiei culturii porumbului. Productia Vegetala. Cereale si Plante Techice, Bucaresti. 38. 3. 3-13.

Szalai, G.-Janda, T.-Páldi, E.-Szigeti, Z. (1996): Role of light in the development of post-chilling symptoms in maize. J. Plant Physiol. 378-383.

Tatum, L. A. (1942): The effect of genetic constitution and processing method on the ability of maize seed to germinate in cold soil. Ph.D. Thesis, Iowa State College, Ames, Iowa, 80.

Tatum, L. A.-Zuber, M. S. (1943): Germination of maize under adverse conditions. J. Am. Soc. Agr., 35. 48-59.

Tomoraga, P.-Mihailescu, I. F.-Chimisliu, C. (1985): Cercetari privind stabilirea epocii optime de insamintare a noilor hibrizi de porumb cultivati in conditile de irigare din Dobrogea. Productia Vegetala. Cereale si Plante Techice, Bucaresti. 37. 12. 3-7. 